\title{
Antiviral activities of atractylon from Atractylodis Rhizoma
}

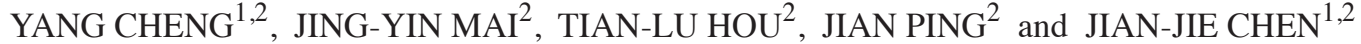 \\ ${ }^{1}$ Department of Infectious Disease, Hospital for Infectious Diseases of Pudong New Area, Shanghai 201299; \\ ${ }^{2}$ Shuguang Hospital Affiliated to Shanghai University of Traditional Chinese Medicine, Shanghai 201203, P.R. China
}

Received February 18, 2016; Accepted September 1, 2016

DOI: $10.3892 / \mathrm{mmr} .2016 .5713$

\begin{abstract}
Atractylodis Rhizoma is a traditional medicinal herb, which has antibacterial, antiviral, anti-inflammatory and anti-allergic, anticancer, gastroprotective and neuroprotective activities. It is widely used for treating fever, cold, phlegm, edema and arthralgia syndrome in South-East Asian nations. In this study, 6 chemical compositions of Atractylodis Rhizoma were characterized by spectral analysis and their antiviral activities were evaluated in vitro and in vivo. Among them, atractylon showed most significant antiviral activities. Atractylon treatment at doses of $10-40 \mathrm{mg} / \mathrm{kg}$ for 5 days attenuated influenza A virus (IAV)-induced pulmonary injury and decreased the serum levels of interleukin (IL)-6, tumor necrosis factor- $\alpha$ and IL-1 $\beta$, but increased interferon- $\beta$ (IFN- $\beta$ ) levels. Atractylon treatment upregulated the expression of Toll-like receptor 7 (TLR7), MyD88, tumor necrosis factor receptor-associated factor 6 and IFN- $\beta$ mRNA but downregulated nuclear factor- $\kappa \mathrm{B}$ p 65 protein expression in the lung tissues of IAV-infected mice. These results demonstrated that atractylon significantly alleviated IAV-induced lung injury via regulating the TLR7 signaling pathway, and may warrant further evaluation as a possible agent for IAV treatment.
\end{abstract}

\section{Introduction}

Influenza A virus (IAV) causes significant epidemics of respiratory disease and deaths in humans (1). The rapidly increasing prevalence of drug resistance and frequent mutations in strain (2), leads to failure of flu vaccine and neuraminidase inhibitor, which demonstrated that there is need for development of novel treatments (3-5). Since IAV infection is a threat to public health, it is critical to develop anti-IAV drug.

Atractylodis Rhizoma is rootstock of Atractylodes lancea (Thunb.) DC. or Atractylodes chinensis (DC.) Koidz., which belongs to the Asteraceae family. This herb is mainly distributed in the region of East China such as Jiangsu,

Correspondence to: Professor Jian-Jie Chen, Department of Infectious Disease, Hospital for Infectious Diseases of Pudong New Area, No. 46 Huaxia East Road 3018 Nong, Shanghai 201299, P.R. China

E-mail: prchenjianjie@126.com

Key words: sesquiterpene lactones, influenza virus, Toll-like receptor 7 , lung injury, inflammation
Henan, Shanxi and Shanxi provinces and is used as crude extracts/decoctions or a component in various herbal formulations for centuries (6). It is described as a basic component of antiviral, anti-inflammatory, hepatoprotective, and anticancer agents. It aids digestion medicines in the authoritative medical book of Ancient China 'Compendium of Materia Medica' and 2015 version of 'Chinese Pharmacopoeia', with daily dose of 3-9 g. In folk medicine, it has been used as a remedy for the treatment of pulmonary and digestive system diseases for several centuries. Especially in Jiangsu, Zhejiang, and other coastal areas, it was always compatible and decocted with other natural medicinal plants (such as Saposhnikoviae Radix and Notopterygii Rhizoma et Radix) to prevent cold and flu in popular medicine (7).

Previously, biological studies reported that it has various pharmacological actions, such as antibacterial, antiviral, anti-inflammatory and anti-allergic, anticancer, gastroprotective and neuroprotective activities (8-11). Results from the toxicity studies in animal models suggested safety profiles of A. lancea and its active constituents. Wang et al in 2015 reported that codonolactone, a sesquiterpene lactone from A. lancea, impaired the development of tumor angiogenesis by downregulating Runx 2 activation to inhibit matrix metalloproteinases expression and vascular endothelial growth factor secretion in endothelial cells (12). Hinesol isolated from essential oils of $A$. lancea rhizome inhibited human leukemia HL-60 cell growth and induced apoptosis through the JNK signaling pathway (13). Atractylenolide I, the major sesquiterpenoid from $A$. lancea, has significant antitumor activity in lung carcinoma cells via a mitochondria-mediated apoptosis pathway (14). Furthermore, atractylenolide III significantly inhibited IgE/Ag-mediated degranulation in RBL-2H3 cells without affecting cell viability (15). The anti-allergic activity of it may depend on the inhibition of Akt, p38, and JNK kinase phosphorylation and $\mathrm{IgE} / \mathrm{Ag}$-mediated $\left[\mathrm{Ca}^{2+}\right] \mathrm{i}$ elevation (16). However, antiviral properties and possible molecular mechanisms of A. lancea extracts and active constituents against IAV-induced lung injury remain unknown. In the present study, protective effects of $A$. lancea extracts and active constituents were investigated in vitro and in vivo.

\section{Materials and methods}

Virus and reagents. The influenza $\mathrm{A} / \mathrm{PR} / 8 / 34$ virus (H1N1 subtype) and A/shenzhen/203/2001 (H3N2 subtype) were donated by Professor Yi-Yu Lu from the Zhejiang Center 


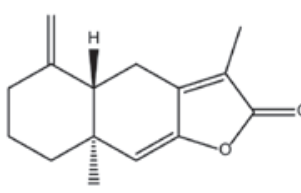

Atractylenolide I (1)

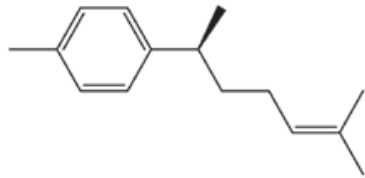

$\alpha$-Curcumene (4)

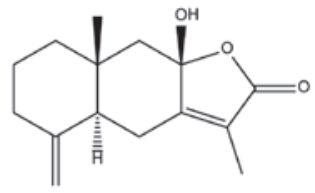

Atractylenolide III (2)

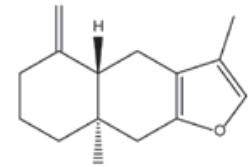

Atractylon (5)

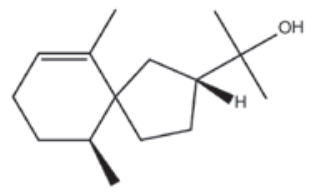

Hinesol (3)

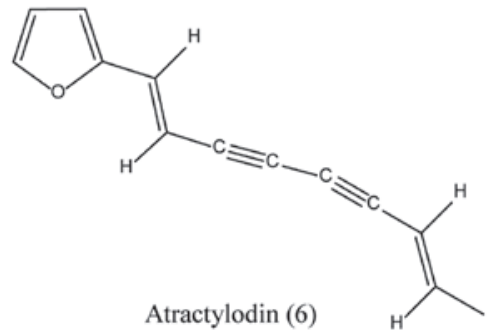

Figure 1. Chemical structures of compounds from Atractylodis Rhizoma extracts.

for Disease Control and Prevention (Zhejiang, China). The infection was induced under ether anesthesia by intranasal inoculation of IAV, which was adapted to mouse lungs with tissue culture infective dose (TCID50) $10^{-3.5}$. This virus caused pneumonia in mice.

Extraction and isolation. The herb was purchased from Huadong Pharmacy (Shanghai, China), and identified by Dr Jiaqi He, Zhejiang Chinese Medical University (Zhejiang, China). The voucher specimen (reference no. Y20141022) has been deposited at Pharmaceutical Department, Zhejiang Medical College (Shanghai, China).

Dried powders of Atractylodis Rhizoma (100 g) was extracted with $600 \mathrm{ml}$ of $95 \%(\mathrm{v} / \mathrm{v})$ ethanol for $2 \mathrm{~h}$ at $90^{\circ} \mathrm{C}$ to give an extract $(9.6 \mathrm{~g})$ which was suspended in $100 \mathrm{ml}$ of deionized water as the test sample 'ethanolic extract'. Another $100 \mathrm{~g}$ of powder was extracted with $600 \mathrm{ml}$ of deionized water for $2 \mathrm{~h}$ at $90^{\circ} \mathrm{C}$, then the supernatant was concentrated to $100 \mathrm{ml}$ as the test sample 'aqueous extract'.

Supercritical carbon dioxide $\left(\mathrm{CO}_{2}\right)$ extraction (SCE) was performed at pressure of 350 bar, temperature of $50^{\circ} \mathrm{C}$ for a duration of 60 min dynamic extraction time using HA121 supercritical fluid extractor (Huaan instrumental factory, Jiangsu, China). Ethanol (99.9\%) was used as modifier with a flow rate of $5 \mathrm{ml} / \mathrm{min}$. The supercritical $\mathrm{CO}_{2}$ flow rate was set at $15 \mathrm{~g} / \mathrm{min}$ and the duration of static extraction time was fixed to $30 \mathrm{~min}$. Solvent was removed and the yield obtained was $5.8 \%$. The concentration of SCE prepared for in vitro studies was $1 \mathrm{mg} / \mathrm{ml}$ in phosphate buffer saline.

The supercritical $\mathrm{CO}_{2}$ extract (50 g) was subjected to a silica gel column using petroleum ether (boiling point $\left.60-90^{\circ} \mathrm{C}\right)$ and EtOAc $(30: 1 \rightarrow 1: 1, \mathrm{v} / \mathrm{v})$ to obtain compound 4 (6 mg), 3 (2 mg), 5 (50 mg), 6 (4 mg), 1 (10 mg) and 2 (13 mg), respectively. The structures of the compounds were determined using spectroscopic techniques including ultraviolet (UV), mass spectrometry, $1 \mathrm{H}$ and 13C NMR spectrometry (Fig. 1).

Antiviral activity and cytotoxicity assay. The anti-viral activities of the extracts and compounds were measured by the cytopathic effect (CPE) inhibition assay (17). Briefly, $100 \mu 1$ of virus suspension (200TCID50) was added to the Madin-Darby canine kidney (MDCK) cells in 96-well plates cultured for $60 \mathrm{~min}$, followed by washing virus with a medium without serum. Then, the medium containing the desired concentration of test compounds was added. After incubation at $37^{\circ} \mathrm{C}$ in a $5 \% \mathrm{CO}_{2}$ incubator for 3 days, the culture was fixed and counted for the plaque numbers. The $\mathrm{IC}_{50}$ of the CPE with respect to virus control was estimated using the Reed-Muench method.

To test for cytotoxicity, $100 \mu \mathrm{l}$ of maintenance medium containing serial 2-fold dilutions of the test compounds was added in 96-well culture plate in which each well contained a concentration of 5,000 cells $/ 100 \mu \mathrm{l}$. Control cells were incubated without test compounds but with DMSO (0.2\%). After cells were cultured at $37^{\circ} \mathrm{C}$ in a $5 \% \mathrm{CO}_{2}$ incubator for 3 days, $20 \mu \mathrm{l}$ of MTT ( $5 \mathrm{mg} / \mathrm{ml}$ in cell culture medium) was added to each well and cells were incubated for an additional $3 \mathrm{~h}$ at $37^{\circ} \mathrm{C}$. The reaction product was determined at $570 \mathrm{~nm}$ with a microplate reader. Cytotoxicity was expressed as the $50 \%$ cell-inhibitory concentration $\left(\mathrm{CC}_{50}\right)$. The selective index (SI) is determined as $\mathrm{CC}_{50} / \mathrm{IC}_{50}$.

Infection model and drug treatment. Male ICR mice of $22 \pm 2 \mathrm{~g}$ weight were anesthetized with $\mathrm{Et}_{2} \mathrm{O}$. Subsequently, animals were intranasally challenged with $20 \mu \mathrm{l}$ of mouse-adapted $10 \mathrm{LD}_{50} \mathrm{IAV}$ and then divided into normal control group, virus control group, ribavirin treatment group and drug treatment groups (24 mice each group). Atractylon or ribavirin was intragastrically administered to experimental groups once daily for 5 days, beginning $2 \mathrm{~h}$ after infection. For the model control group, the mice were only given saline at the same intervals. The mice were observed daily for changes in weight, and survivability (18). To monitor the histological changes and challenge dose of the virus in the lungs of IAV-infected animal, 10 mice per group were sacrificed to calculate lung index and viral load after day 6 post-infection.

Serum cytokine analysis. After 5 days of treatment, the body weight of the animals were measured on sacrifice. Blood samples were collected and centrifuged at 3,000 x g for $20 \mathrm{~min}$ to obtain the serum, which was stored at $4^{\circ} \mathrm{C}$ until use. The serum levels of interferon- $\beta$ (IFN- $\beta$ ), interleukin (IL)-6, tumor necrosis factor (TNF)- $\alpha$, and IL-1 $\beta$ were determined 
Table I. Sequences of primers used for the RT-qPCR assays.

\begin{tabular}{|c|c|c|c|}
\hline Gene & Primer sequences $\left(5^{\prime}-3^{\prime}\right)$ & Size (bp) & Annealing $\left({ }^{\circ} \mathrm{C}\right)$ \\
\hline \multirow[t]{2}{*}{ TLR7 } & F: GGCATTCCCACTAACACCACCAA & \multirow[t]{2}{*}{143} & \multirow[t]{2}{*}{63} \\
\hline & R: GCTTTGGACCCCAGTAGAACAGG & & \\
\hline \multirow[t]{2}{*}{ TRAF6 } & F: GAATCACTTGGCACGACACTT & \multirow[t]{2}{*}{227} & \multirow[t]{2}{*}{63} \\
\hline & R: GAGTTTCCATTTTGGCAGTCA & & \\
\hline \multirow[t]{2}{*}{ MyD88 } & F: GGATGGTAGTGGTTGTCTCTGA & \multirow[t]{2}{*}{145} & \multirow[t]{2}{*}{63} \\
\hline & R: CTGGGGAACTCTTTCTTCATTG & & \\
\hline \multirow[t]{2}{*}{ IFN- $\beta$} & F: АТССТCCAAACAACTCTCCTGT & \multirow[t]{2}{*}{105} & \multirow[t]{2}{*}{63} \\
\hline & R: CTCCTGACACTCCAAACTGCT & & \\
\hline \multirow[t]{2}{*}{$18 \mathrm{~S}$ (internal reference) } & F: CGGACACGGACAGGATTGACA & \multirow[t]{2}{*}{94} & \multirow[t]{2}{*}{63} \\
\hline & R: CCAGACAAATCGCTCCACCAACTA & & \\
\hline
\end{tabular}

RT-qPCR, reverse transcription quantitative polymerase chain reaction; TLR7, Toll-like receptor 7; TRAF6, tumor necrosis factor receptor-associated factor 6 ; IFN- $\beta$, interferon- $\beta$.

Table II. Antiviral activities of Atractylodis Rhizoma extracts and compounds against influenza virus in MDCK cells by the CPE assay.

\begin{tabular}{|c|c|c|c|c|c|}
\hline \multirow[b]{2}{*}{ Samples } & \multicolumn{2}{|c|}{ H1N1 } & \multicolumn{2}{|c|}{$\mathrm{H} 3 \mathrm{~N} 2$} & \multirow[b]{2}{*}{ SI } \\
\hline & $\mathrm{CC}_{50}$ & $\mathrm{IC}_{50}$ & SI & $\mathrm{IC}_{50}$ & \\
\hline Ethanolic extract & 885.0 & 348.7 & 2.5 & 350.4 & 2.5 \\
\hline Supercritical $\mathrm{CO}_{2}$ extract & 1407.5 & 294.4 & 4.8 & 310.3 & 4.5 \\
\hline Aqueous extract & 1335.0 & ND & ND & ND & ND \\
\hline Atractylenolide I & 203.5 & 24.1 & 8.4 & 35.1 & 5.8 \\
\hline Atractylenolide III & 191.2 & 24.4 & 7.8 & 28.6 & 6.7 \\
\hline Hinesol & 181.3 & 54.2 & 3.3 & 51.2 & 3.5 \\
\hline$(+)$ - $\alpha$-curcumene & 137.7 & 18.4 & 7.5 & 22.1 & 6.2 \\
\hline Atractylodin & 162.4 & ND & ND & ND & ND \\
\hline Atractylon & 261.4 & 8.9 & 29.4 & 9.4 & 27.8 \\
\hline Ribavirin & 116.30 & 14.2 & 8.2 & 10.7 & 10.9 \\
\hline
\end{tabular}

ND, not determined; MDCK, Madin-Darby canine kidney; CPE, cytopathic effect; SI, selective index.

by enzyme linked immunosorbent assay (ELISA). The ELISA kits used in this study were obtained from Bioval Technologies (Shanghai, China).

Histopathology. The whole lungs of 10 mice in each group were removed. A portion of each lung was dissected and fixed in a $10 \%$ neutral buffered formalin solution. The remaining lung tissue was quickly frozen and kept at $-80^{\circ} \mathrm{C}$ for biochemical analysis. The fixed tissues were routinely processed, embedded in paraffin, sectioned $(4 \mu \mathrm{m})$, deparaffinized, and rehydrated according to standard techniques. The tissue sections were stained with hematoxylin and eosin.

Reverse transcription quantitative polymerase chain reaction (RT-qPCR). The mouse lung samples were homogenized and extracted with TRIzol reagents to obtain the total RNAs (Biotechnology Co., Ltd., Shanghai, China). The cDNA was synthesized according to the kit protocol (Takara Bio, Dalian, China). The specific primer pairs [i.e., Toll-like receptor 7 (TLR-7), MyD88, tumor necrosis factor receptor-associated factor 6 (TRAF6) and IFN- $\beta$ and 18sRNA] were designed and used for the analysis as shown in Table I. These primers were synthesized by the Biotechnology Co., Ltd. The eukaryotic 18S rRNA was primarily selected as the housekeeping gene in this study because of the limited change in its expression under different experimental conditions.

The amplification reaction was conducted in a $25 \mu \mathrm{l}$ glass capillary containing $2 \mu \mathrm{l}$ of cDNA, $0.5 \mu \mathrm{l}$ of each of the forward and reverse primers (i.e., final concentration of each, $0.5 \mu \mathrm{M}$ ), $12.5 \mu \mathrm{l} 2 \mathrm{X}$ SYBR-Green, and nuclease-free water for a final volume of $25 \mu \mathrm{l}$ for each reaction. The following thermal profile for the RT-qPCR assays was used in all the primer sets: $95^{\circ} \mathrm{C}$ for $1 \mathrm{~min}$, followed by 40 cycles of denaturation at $95^{\circ} \mathrm{C}$ for $10 \mathrm{sec}$, annealing at $55^{\circ} \mathrm{C}$ for $25 \mathrm{sec}$, and elongation 
Table III. Inhibition of atractylon and ribavirin on IVA-induced acute lung injury.

\begin{tabular}{lcccc}
\hline Groups & Dose $(\mathrm{mg} / \mathrm{kg})$ & Lung index $(\mathrm{mg} / \mathrm{g})$ & Inhibitory rate $(\%)$ & Viral load $\left(\mathrm{x} 10^{6}\right.$ copies $)$ \\
\hline Normal control & - & $7.35 \pm 0.51^{\mathrm{b}}$ & - & - \\
Model control & - & $21.26 \pm 4.75$ & - & $6.69 \pm 0.74$ \\
Ribavirin & 50 & $12.68 \pm 3.30^{\mathrm{b}}$ & 61.7 & $1.38 \pm 0.56^{\mathrm{b}}$ \\
Atractylon & 40 & $10.90 \pm 3.76^{\mathrm{b}}$ & 74.5 & $0.36 \pm 0.15^{\mathrm{b}}$ \\
& 20 & $13.08 \pm 4.54^{\mathrm{b}}$ & 58.8 & $2.56 \pm 0.72^{\mathrm{b}}$ \\
& 10 & $17.43 \pm 4.16^{\mathrm{a}}$ & 27.5 & $4.79 \pm 0.84^{\mathrm{b}}$ \\
\hline
\end{tabular}

Compared with model control group, ${ }^{\mathrm{a}} \mathrm{P}<0.05$, ${ }^{\mathrm{b}}<0.01$. Data shown are means \pm standard deviation $(\mathrm{n}=10)$. IVA, influenza A virus.

Table IV. Protective effects of atractylon and ribavirin in IVA-infected mice.

\begin{tabular}{|c|c|c|c|c|c|}
\hline Groups & Dose (mg/kg) & Survived/total & Survival rate $(\%)$ & $\mathrm{MDD} \pm \mathrm{SD}$ & Life prolong rate $(\%)$ \\
\hline Normal control & - & $20 / 20$ & 100.0 & $14.0 \pm 0.0^{\mathrm{a}}$ & - \\
\hline Model control & - & $3 / 20$ & 15.0 & $7.9 \pm 2.8$ & - \\
\hline Ribavirin & 50 & $10 / 20$ & 50.0 & $11.1 \pm 3.1^{\mathrm{a}}$ & 40.5 \\
\hline \multirow[t]{3}{*}{ Atractylon } & 40 & $14 / 20$ & 70.0 & $12.4 \pm 2.6^{\mathrm{a}}$ & 57.0 \\
\hline & 20 & $11 / 20$ & 55.0 & $11.2 \pm 3.3^{\mathrm{a}}$ & 41.8 \\
\hline & 10 & $6 / 20$ & 30.0 & $9.3 \pm 3.6^{\mathrm{a}}$ & 17.7 \\
\hline
\end{tabular}

Survival rate, the survival rate of the animals; MDD, mean day to death; SD, standard deviation. Compared with model control group, ${ }^{\mathrm{a}} \mathrm{P}<0.01$. IVA, influenza A virus.

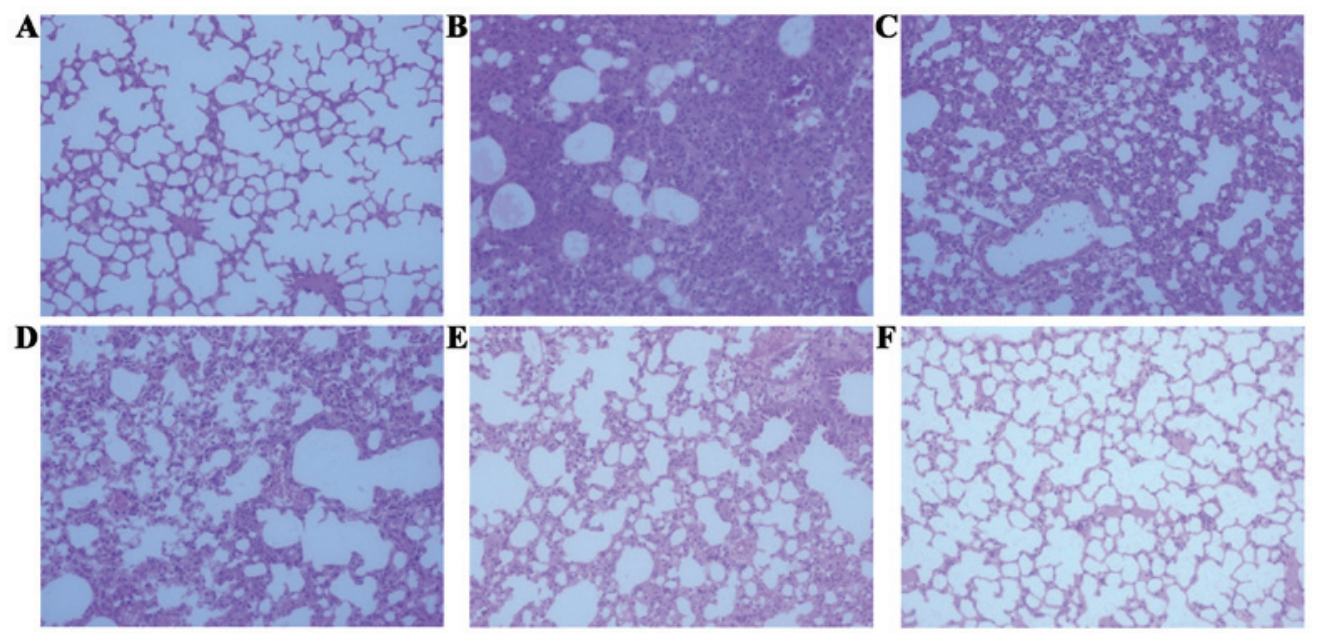

Figure 2. Effects of atractylon on influenza A virus (IAV)-induced acute lung injury. Lungs from each experimental group were processed for histological evaluation. (A) Lung section from the normal control group; (B) lung section from model control group; (C) lung section from IVA-infected and treated with ribavirin $(50 \mathrm{mg} / \mathrm{kg}$ ). (D-F) The lung section from the IVA-infected and treated with 10, 20 and $40 \mathrm{mg} / \mathrm{kg}$ of atractylon, respectively. Representative histological tissue sections were stained with hematoxylin and eosin.

at $64^{\circ} \mathrm{C}$ for $25 \mathrm{sec}$ with the acquisition of fluorescent data. The relative expression levels of the genes were calculated using the $2^{-\Delta \Delta \mathrm{Ct}} \times 10^{6}$ method.

Statistical analysis. All the values were expressed as mean values \pm standard deviation. All statistical analyses were performed using one-way ANOVA followed by the Tukey's post hoc test. $\mathrm{P}<0.05$ was considered to indicate a statistically significant difference.

\section{Results and Discussion}

Atractylodis Rhizoma has been used for treatment of infections in the upper respiratory tract for thousands of years in 
Table V. Effects of atractylon on serum cytokines in IVA-infected mice.

\begin{tabular}{lccccc}
\hline Groups & Dose $(\mathrm{mg} / \mathrm{kg})$ & IFN- $\beta(\mathrm{pg} / \mathrm{ml})$ & IL-6 $(\mathrm{pg} / \mathrm{ml})$ & TNF- $\alpha(\mathrm{pg} / \mathrm{ml})$ & $\mathrm{IL}-1 \beta(\mathrm{pg} / \mathrm{ml})$ \\
\hline Normal control & - & $22.9 \pm 2.75$ & $13.6 \pm 1.21^{\mathrm{b}}$ & $8.64 \pm 1.09^{\mathrm{b}}$ & $9.15 \pm 0.38^{\mathrm{b}}$ \\
Model control & - & $24.5 \pm 2.52$ & $29.8 \pm 2.66$ & $18.9 \pm 1.37$ & $21.3 \pm 2.06$ \\
Ribavirin & 50 & $23.3 \pm 2.79$ & $18.5 \pm 5.99^{\mathrm{b}}$ & $13.4 \pm 1.54^{\mathrm{b}}$ & $21.6 \pm 3.36$ \\
Atractylon & 40 & $30.8 \pm 3.31^{\mathrm{b}}$ & $12.8 \pm 1.16^{\mathrm{b}}$ & $9.20 \pm 0.77^{\mathrm{b}}$ & $13.4 \pm 0.74^{\mathrm{b}}$ \\
& 20 & $29.4 \pm 3.27^{\mathrm{a}}$ & $17.4 \pm 1.11^{\mathrm{b}}$ & $11.8 \pm 1.94^{\mathrm{b}}$ & $16.5 \pm 1.17^{\mathrm{b}}$ \\
& 10 & $25.8 \pm 2.87$ & $19.5 \pm 2.76^{\mathrm{b}}$ & $16.2 \pm 2.27^{\mathrm{a}}$ & $17.2 \pm 1.35^{\mathrm{b}}$ \\
\hline
\end{tabular}

Compared with model control, ${ }^{\mathrm{a}} \mathrm{P}<0.05,{ }^{\mathrm{b}} \mathrm{P}<0.01$. Data denoted are means \pm standard deviation $(\mathrm{n}=10)$. IVA, influenza A virus; IFN- $\beta$, interferon- $\beta$; IL, interleukin; TNF- $\alpha$, tumor necrosis factor- $\alpha$.

Asia (19). To elucidate its mechanism and chemical basis, the extracts of the herb for antiviral activities in MDCK cells were assessed by CPE reduction assay. To obtain the bioactive component related to its antiviral activity, the herb was extracted with water, ethanol and supercritical $\mathrm{CO}_{2}$ to obtain different polar extraction. Among these polar extractions, SCE showed the highest antiviral activity by CPE assay (Table II). To clarify the chemical compositions of SCE, the mobile phase consisted of petroleum ether and EtOAc was used as gradient elution for separation with the silica gel column. Six compounds were isolated and then identified by using spectroscopic techniques including UV, mass spectrometry, $1 \mathrm{H}$ and 13C NMR spectrometry. Compared with the spectral data reported in previous literature (20-22), their chemical structures were characterized to be atractylenolide I (1), atractylenolide III (2), hinesol, $\alpha$-curcumene (4), atractylon (5) and atractylodin (6), respectively, as shown in Fig. 1.

The CPE assay showed that except atractylodin, another 5 compounds had obvious antiviral activities. In particular, the sesquiterpene lactone atractylon had most potent bioactivity with values of SI (29.4 for H1N1 and 27.8 for H3N2), which were approximately 3 -fold higher than those of ribavirin. Recently, many reports have shown that sesquiterpene lactones as a large class of polyphenolic compounds in our daily food and plants have been paid more attention due to their various pharmacological activities such as anti-cancer, anti-inflammatory, antimicrobial, antioxidant and antiviral activities (23-27). Previous studies also proved that the spatial arrangement of the terpenoid skeleton fused with an $\alpha$-methylene- $\gamma$-lactone moiety produces maximal antiviral activity (28). Our findings showed that the sesquiterpene lactones (atractylenolide I, atractylenolide III and atractylon) inhibited the formation of agglutination by IAV suggested the mechanism of the compounds against influenza virus might be related to blocking the adsorption of the virus to host cells or inhibiting the replication of virus, but further investigations have to be done.

To evaluate pharmacodynamic action of atractylon thoroughly, protective effects of atractylon on IAV-induced lung injury and death were observed in vivo. The histological changes in the lungs of the mice were noted with the aggravation of the infection. After IAV challenge, lung index was obviously increased compared to the normal control group (Table III) since IAV causes red blood cell agglutination and monocytic infiltration, resulting in interstitial pneumonia and progressive
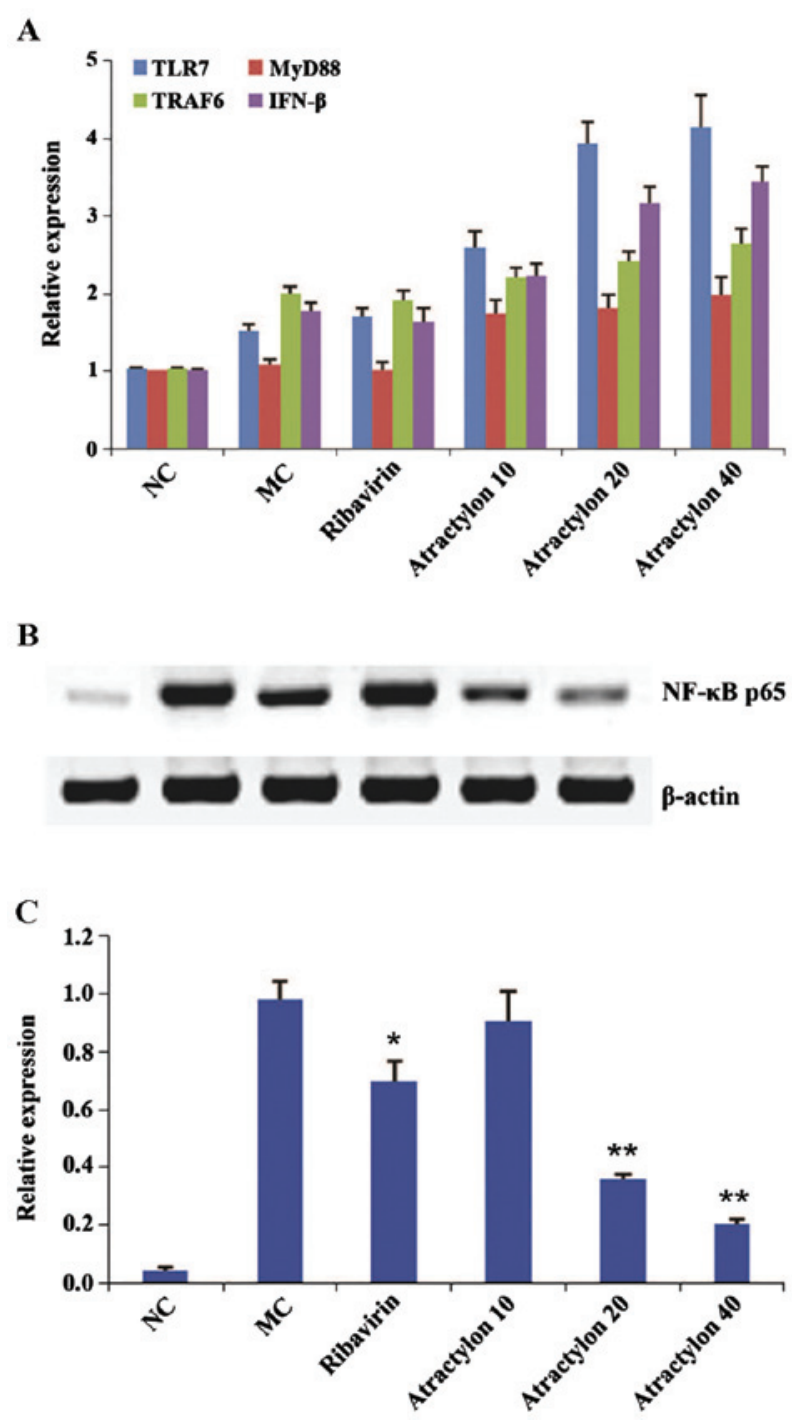

Figure 3. Effects of atractylon on Toll-like receptor 7 (TLR7) signaling regulators of lung tissues in influenza A virus (IAV)-infected mice. (A) Real-time fluorescence quantitative polymerase chain reaction analysis of TLR7, MyD88, tumor necrosis factor receptor-associated factor 6 (TRAF6) and interferon- $\beta$ (IFN- $\beta$ ) mRNA expression. (B) Western blotting of nuclear factor $-\kappa \mathrm{B}(\mathrm{NF}-\kappa \mathrm{B}) \mathrm{p} 65$ protein expressions. NC, normal control group; MC, model control group; Atractylon 10, IAV-infected mice treated with atractylon (10 mg/kg). (C) Quantification of western blotting, values indicate fold changes compared with internal control (18S rRNA or $\beta$-actin). Data are presented as means \pm standard deviation. Compared with model control group, ${ }^{*} \mathrm{P}<0.05,{ }^{* *} \mathrm{P}<0.01$. 
lung weight $(29,30)$. The IAV-induced lung injury characterized by the presence of interstitial edema, hemorrhage and infiltration of inflammatory cells could also be observed in the tissues (Fig. 2). However, oral administration with atractylon or ribavirin daily for 5 days could significantly inhibit lung indexes $(\mathrm{P}<0.05)$. Moreover, the inhibition of atractylon was found to proportionally increase in a dose-dependent manner. The histological damage was improved by the atractylon treatment $(10-40 \mathrm{mg} / \mathrm{kg})$. To monitor the infectivity and challenge dose of the virus in mouse lung, we also determined the viral loads in the lung by RFQ-PCR analysis (Table IV). Viral loads in the atractylon-treated groups were drastically reduced compared with that in the model group $(\mathrm{P}<0.01)$. These results were in accordance with the CPE assay, indicating that atractylon could directly inhibit viral replication.

Innate immunity is the primary line of antiviral defense (31). This type of immunity allows the infected and neighboring cells to establish an early antiviral state in the host after virus exposure. Innate immunity also prepares the adaptive immune response and recognizes viral components through pattern recognition receptors (PRRs) during infection. IAV infection is recognized through two classic adaptors of PRRs to induce robust type I IFN (IFN- $\alpha / \beta)$ responses; these PRR pathways involve TLR7 in the endosome, which converge on TRAF6, interferon regulatory factor 3 (IRF3) and IRF7 to induce the production of proinflammatory cytokines and type I IFNs (32-35). The induction of pro-inflammatory cytokines and IFNs is important to induce antiviral gene expression, which interfere with viral replication, recruit leukocytes and lymphocytes to the infection part, and provide the requisite signals, thereby activating the adaptive immune response for efficient viral clearance $(36,37)$.

The serum levels of IFN- $\alpha$, IL-1 $\beta$, IL- 6 and TNF- $\alpha$ were measured to observe the inflammatory cytokine levels of peripheral blood during IAV infection. In this study, it was found that the administration of atractylon significantly increased the serum levels of IFN- $\beta$ but decrease the levels of other pro-inflammatory cytokines (IL-6, TNF- $\alpha$ and IL-1 $\beta$ ) as shown in Table V. Previous studies have shown that IFN- $\beta$ has an important role in the control of influenza infection. By contrast, the mRNA expressions of TLR7 and its downstream genes MyD88, TRAF6 and IFN- $\beta$ were obviously upregulated $(\mathrm{P}<0.01)$ compared with the model control group (Fig. 3), which indicated that the above-mentioned pathway was activated. Furthermore, the results of the western blot analysis showed that the expression levels of nuclear factor $-\kappa \mathrm{B}(\mathrm{NF}-\kappa \mathrm{B}) \mathrm{p} 65$ proteins in the model control group were significantly increased compared with the normal control group $(\mathrm{P}<0.01)$. However, the protein expressions in the atractylon-treatment groups were significantly increased $(\mathrm{P}<0.01)$. It is well known that $\mathrm{NF}-\kappa \mathrm{B}$ p65 is the most crucial inflammatory protein of TLR7 downstream factors, which can transfer to the cell nucleus and cause proinflammatory cytokine release, had a lower expression (38-40). These findings were also consistent with above analysis of serum pro-inflammatory cytokines. Therefore, these combined results suggested that the effects of atractylon during IAV infection were partially-dependent on the activation of TLR7 pathway to induce the type I IFN production and NF- $\kappa \mathrm{B}$ p65 inhibition.
In summary, a SCE prepared from Atractylodis Rhizoma showed potential inhibition against IAV. Six compounds isolated from SCE were characterized by spectral analysis to be atractylenolide I, atractylenolide III, hinesol, $\alpha$-curcumene, atractylon and atractylodin. Among these, atractylon had the most significant anti-IAV activities and highest SI values in vitro. Treatment of atractylon also significantly alleviated pulmonary inflammation in IAV-infected mice, and protective effects of atractylon might be related to its activation of TLR7 to induce the production of type I IFNs, but to inhibit NF- $\kappa \mathrm{B}$ activation. These findings suggested that atractylon may warrant further evaluation as a possible agent for influenza treatment.

\section{Acknowledgements}

This study was supported by 3-year plan of action of traditional Chinese medicine in Shanghai (nos. ZY3-JSFC-1-1011 and ZY3-RCPY-1-1001), Shanghai Pudong New Area Commission of Health and Family Control (no. PDYNZJ2014-08), and Shanghai Legendary Medical Practitioner of TCM CHEN Jian-jie Studio (no. ZYSNXD-CC-MZY003).

\section{References}

1. Richard M and Fouchier RA: Influenza A virus transmission via respiratory aerosols or droplets as it relates to pandemic potential. FEMS Microbiol Rev 40: 68-85, 2016.

2. Li TC, Chan MC and Lee $\mathrm{N}$ : Clinical implications of antiviral resistance in influenza. Viruses 7: 4929-4944, 2015.

3. Shen Z, Lou K and Wang W: New small-molecule drug design strategies for fighting resistant influenza A. Acta Pharm Sin B 5: 419-430, 2015

4. Watanabe $\mathrm{T}$ and Kawaoka Y: Influenza virus-host interactomes as a basis for antiviral drug development. Curr Opin Virol 14: 71-78, 2015

5. Ganjhu RK, Mudgal PP, Maity H, Dowarha D, Devadiga S, Nag S and Arunkumar G: Herbal plants and plant preparations as remedial approach for viral diseases. Virusdisease 26: 225-236, 2015.

6. Koonrungsesomboon $\mathrm{N}$, Na-Bangchang $\mathrm{K}$ and Karbwang J: Therapeutic potential and pharmacological activities of Atractylodes lancea (Thunb.) DC. Asian Pac J Trop Med 7: 421-428, 2014.

7. Zhong Y, Wang X, Xu G, Mao B, Zhou W, Min J, Jiang H, Diao X and Fu J: Modified Yupingfeng formula for the treatment of stable chronic obstructive pulmonary disease: A systematic review of randomized controlled trials. Afr J Tradit Complement Altern Med 11: 1-14, 2013.

8. Xu J, Chen D, Liu C, Wu XZ, Dong CX and Zhou J: Structural characterization and anti-tumor effects of an insulin-type fructan from Atractylodes chinensis. Int J Biol Macromol 82: 765-771, 2016.

9. Wang C, He L, Wang N and Liu F: Screening anti-inflammatory components from Chinese traditional medicines using a peritoneal macrophage/cell membrane chromatography-offline-GC/MS method. J Chromatogr B Analyt Technol Biomed Life Sci 877: 3019-3024, 2009.

10. Zhang JL, Huang WM and Zeng QY: Atractylenolide I protects mice from lipopolysaccharide-induced acute lung injury. Eur J Pharmacol 765: 94-99, 2015.

11. JiZH,Liu C, Zhao H and Yu XY: Neuroprotective effect of biatractylenolide against memory impairment in D-galactose-induced aging mice. J Mol Neurosci 55: 678-683, 2015.

12. Wang S, Cai R, Ma J, Liu T, Ke X, Lu H and Fu J: The natural compound codonolactone impairs tumor induced angiogenesis by downregulating BMP signaling in endothelial cells. Phytomedicine 22: 1017-1026, 2015.

13. Masuda Y,Kadokura T, Ishii M, Takada K and Kitajima J: Hinesol, a compound isolated from the essential oils of Atractylodes lancea rhizome, inhibits cell growth and induces apoptosis in human leukemia HL-60 cells. J Nat Med 69: 332-339, 2015. 
14. Liu H, Zhu Y, Zhang T, Zhao Z, Zhao Y, Cheng P, Li H, Gao H and Su X: Anti-tumor effects of atractylenolide I isolated from Atractylodes macrocephala in human lung carcinoma cell lines. Molecules 18: 13357-13368, 2013.

15. Ji GQ, Chen RQ and Wang L: Anti-inflammatory activity of atractylenolide III through inhibition of nuclear factor- $\kappa \mathrm{B}$ and mitogen-activated protein kinase pathways in mouse macrophages. Immunopharmacol Immunotoxicol 15: 1-5, 2015

16. Zhang NN, Park DK and Park HJ: The inhibitory activity of atractylenolide III, a sesquiterpenoid, on IgE-mediated mast cell activation and passive cutaneous anaphylaxis (PCA). J Ethnopharmacol 145: 278-285, 2013.

17. Wu Q, Yu C, Yan Y, Chen J, Zhang C and Wen X: Antiviral flavonoids from Mosla scabra. Fitoterapia 81: 429-433, 2010.

18. Yu CH, Yu WY, Fang J, Zhang HH, Ma Y, Yu B, Wu F and Wu XN: Mosla scabra flavonoids ameliorate the influenza A virus-induced lung injury and water transport abnormality via the inhibition of PRR and AQP signaling pathways in mice. J Ethnopharmacol 179: 146-155, 2016

19. Chen ZB: Study and application of herbal disinfectants in China Biomed Environ Sci 17: 492-498, 2004.

20. Zhao $\mathrm{C}$ and He C: Preparative isolation and purification of atractylon and atractylenolide III from the Chinese medicinal plant atractylodes macrocephala by high-speed counter-current chromatography. J Sep Sci 29: 1630-1636, 2006.

21. Li CQ, He LC, Dong HY and Jin JQ: Screening for the anti-inflammatory activity of fractions and compounds from Atractylodes macrocephala koidz. J Ethnopharmacol 114: 212-217, 2007

22. Li J, Li F, Xu Y, Yang W, Qu L, Xiang Q, Liu C and Li D: Chemical composition and synergistic antioxidant activities of essential oils from Atractylodes macrocephala and Astragalus membranaceus. Nat Prod Commun 8: 1321-1324, 2013.

23. Ozçelik B, Gürbüz I, Karaoglu T and Yeşilada E: Antiviral and antimicrobial activities of three sesquiterpene lactones from Centaurea solstitialis L. ssp. solstitialis. Microbiol Res 164: 545-552, 2009

24. Zhang HJ, Nguyen VH, Nguyen MC, Soejarto DD, Pezzuto JM, Fong HH and Tan GT: Sesquiterpenes and butenolides, natura anti-HIV constituents from Litsea verticillata. Planta Med 71 452-457, 2005

25. Harmatha J, Vokáč K, Buděšínský M,Zídek Z and Kmoníčková E: Immunobiological properties of sesquiterpene lactones obtained by chemically transformed structural modifications of trilobolide. Fitoterapia 107: 90-99, 2015.

26. De Ford C, Ulloa JL, Catalán CA, Grau A, Martino VS, Muschietti LV and Merfort I: The sesquiterpene lactone polymatin B from Smallanthus sonchifolius induces different cell death mechanisms in three cancer cell lines. Phytochemistry 117: 332-339, 2015
27. Felix S, Sandjo LP, Opatz T and Erkel G: Anti-inflammatory drimane sesquiterpene lactones from an Aspergillus species. Bioorg Med Chem 22: 2912-2918, 2014

28. Hwang DR, Wu YS, Chang CW, Lien TW, Chen WC, Tan UK, Hsu JT and Hsieh HP: Synthesis and anti-viral activity of a series of sesquiterpene lactones and analogues in the subgenomic HCV replicon system. Bioorg Med Chem 14: 83-91, 2006

29. Guo J, Cao Y, Qin K, Zhao X, Wang D, Li Z, Xin L, Shu $Y$ and Zhou J: Limited effect of recombinant human mannose-binding lectin on the infection of novel influenza $A$ (H7N9) virus in vitro. Biochem Biophys Res Commun 458: 77-81, 2015.

30. Sawai-Kuroda R, Kikuchi S, Shimizu YK, Sasaki Y, Kuroda K, Tanaka T, Yamamoto T, Sakurai K and Shimizu K: A polyphenol-rich extract from Chaenomeles sinensis (Chinese quince) inhibits influenza A virus infection by preventing primary transcription in vitro. J Ethnopharmacol 146: 866-872, 2013.

31. Chen S, Cheng A and Wang M: Innate sensing of viruses by pattern recognition receptors in birds. Vet Res 44: 82, 2013

32. Raj RS, Bonney EA and Phillippe M: Influenza, immune system, and pregnancy. Reprod Sci 21: 1434-1451, 2014.

33. Yoo JK, Kim TS, Hufford MM and Braciale TJ: Viral infection of the lung: Host response and sequelae. J Allergy Clin Immunol 132: 1263-1276, 2013.

34. Ichinohe T: Respective roles of TLR, RIG-I and NLRP3 in influenza virus infection and immunity: Impact on vaccine design. Expert Rev Vaccines 9: 1315-1324, 2010.

35. Dash P and Thomas PG: Host detection and the stealthy phenotype in influenza virus infection. Curr Top Microbiol Immunol 386: 121-147, 2015

36. Ramirez-Ortiz ZG, Prasad A, Griffith JW, Pendergraft WF III, Cowley GS, Root DE, Tai M, Luster AD, El Khoury J, Hacohen N, et al: The receptor TREML4 amplifies TLR7-mediated signaling during antiviral responses and autoimmunity. Nat Immunol 16: 495-504, 2015.

37. Goff PH, Hayashi T, Martínez-Gil L, Corr M, Crain B, Yao S, Cottam HB, Chan M, Ramos I, Eggink D, et al: Synthetic Toll-like receptor 4 (TLR4) and TLR7 ligands as influenza virus vaccine adjuvants induce rapid, sustained, and broadly protective responses. J Virol 89: 3221-3235, 2015.

38. Ramos I and Fernandez-Sesma A: Modulating the innate immune response to influenza A virus: Potential therapeutic use of anti-inflammatory drugs. Front Immunol 6: 361, 2015.

39. Kell AM and Gale M Jr: RIG-I in RNA virus recognition. Virology 479-480: 110-121, 2015.

40. Gambhir S, Vyas D, Hollis M, Aekka A and Vyas A: Nuclear factor kappa B role in inflammation associated gastrointestinal malignancies. World J Gastroenterol 21: 3174-3183, 2015. 